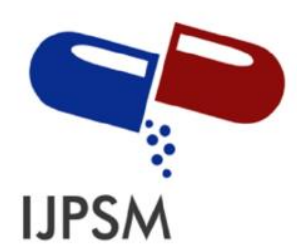

Suryani Iskandi et al, Int. Journal of Pharmaceutical Sciences and Medicine (IJPSM),

Vol.6 Issue. 8, August- 2021, pg. 182-186

ISSN: 2519-9889

Impact Factor: 3.426

\title{
Review: Antibacterial Activity of Syzygium polyanthum
}

\author{
Suryani Iskandi; Fitra Fauziah; Sri Oktavia \\ School of Pharmaceutical Science (STIFARM) Padang, West Sumatera, 25175, Indonesia \\ Email: fitrafauziah@stifarm-padang.ac.id \\ DOI: 10.47760/ijpsm.2021.v06i08.014
}

\begin{abstract}
Syzygium polyanthum is a species of the Myrtaceae family, used as traditional medicine by various ethnic groups, especially in Southeast Asia. Based on the studies, it has antibacterial activity. This article aims to review the studies about the antibacterial activity of S.polyanthum. Literature studies were used in the article review for 20 last years (20102020) from trusted online databases (ScienceDirect, NCBI, Researchgate, Google Scholar, and other publishers and trusted journals. The results showed that S.polyanthum had a significant effect in inhibiting the growth of bacteria likes Escherichia coli, Streptococcus mutans, Staphylococcus aureus, and Salmonella. It can be a conclusion that S.polyanthum has the potential to develop as antibacterial therapy.

Keywords: antibacterial, Syzygium polyanthum, traditional medicine
\end{abstract}

\section{Introduction}

Syzygium polyanthum is a species of the Myrtaceae family, used as a spice in cooking and medicine, especially in Southeast Asia, Malaysia, and Indonesia [1]. S. polyanthum has synonyms Eugenia polyantha Wight, Euginia nitida Duthie, Euginia balsamea Ridley [2]. S. polyanthum is also used as a traditional medicine to treat diabetes mellitus, gastric disorders, hemorrhoids, diarrhea, hypertension, and reduce cholesterol levels [3]. A study about the pharmacological activity of S.polyanthum showed that it has pharmacology. S. polyanthum has antihypertensive, antidiabetic, antioxidant, anti-inflammatory, immunomodulatory, antibacterial, and anticancer activities [4].

Phytochemical analysis showed that $S$. polyanthum contained flavonoids, alkaloids, terpenoids, tannins, and saponins [5]. The pharmacological activity of $S$ polyanthum is related to its secondary metabolites. $S$. polyanthum extract dissolved in a water solvent tested on male mice could reduce the average blood pressure. TerpeNoid compounds, phenolics (e.g., eugenol), tannins, and flavonoids are responsible for the antihypertensive effect. Eugenol has vasorelaxants so that it can lower blood pressure [6]. S.polyanthum extract could reduce blood glucose levels. It was equivalent to glibenclamide which was used as a positive control [7]. S.polyanthum extract can inhibit free radicals. At a concentration of $50 \mathrm{ppm}$, S.polyanthum extract could inhibit $82 \%$ of free radicals [8]. S.polyanthum extract can inhibit Methicillin-Resistant Staphylococcus aureus (MRSA) bacteria growth. Its ability was equivalent to ampicillin [9]. Using the disk diffusion method showed that $S$. polyanthum extract had good activity as an antibacterial, especially for Salmonella thypii and Bacillus cereus [8]. Some studies showed that these compounds have antibacterial activity [10]. This article aims to review studies on the antibacterial activity of $S$.polyanthum.

\section{Data Collection}

In compiling review articles, the technique was used by literature studies to finding sources or literature from primary articles in the last 20 years (2010-2020). Also, in making this review article, data were searched using 


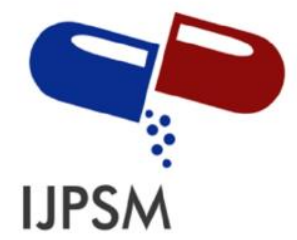

\section{Suryani Iskandi et al, Int. Journal of Pharmaceutical Sciences and Medicine (IJPSM), Vol.6 Issue. 8, August- 2021, pg. 182-186}

ISSN: 2519-9889

Impact Factor: 3.426

the keywords "antibacterial" and "Syzygium polyanthum" from trusted websites such as ScienceDirect, NCBI, Researchgate, Google Scholar, and others published and trusted journals.

\section{Result and Discussion}

Table 1 was showed the results of review studies about the antibacterial activity of S.polyanthum. The ethaNolic extract of S.polyanthum leaves was used to test the antibacterial activity using the disk diffusion test method and determine the MIC and MBC value. Bacteria used Escherichia coli, Klebsiella pneumonia, Listeria monocytogenes, Pseudomonas aeruginosa, Proteus mirabilis, Staphylococcus aureus, Salmonella typhimurium, Vibrio cholerae, Vibrio parahaemolyticus. By the disk diffusion test method, the zone of inhibition is obtained Escherichia coli $7.00 \pm 0.28$, Klebsiella pneumonia $9.33 \pm 0.50$, Listeria monocytogenes $9.67 \pm 0.58$, Pseudomonas aerugiNosa $7.00 \pm 0.32$, Proteus mirabilis $6.67 \pm 0.40$, Staphylococcus aureus 9.33 \pm 0.52 , Salmonella typhimurium $6.67 \pm 0.50$, Vibrio cholerae $8.33 \pm 0.30$, Vibrio parahaemolyticus $6.67 \pm$ 0.50. Determination of the MIC value of Escherichia coli 1.25, Klebsiella pneumonia 1.25, Listeria monocytogenes 0.63, Pseudomonas aerugiNosa 1.25, Proteus mirabilis 1.25, Staphylococcus aureus 0.63, Salmonella typhimurium 1.25, Vibrio cholerae 1.25, Vibrio parahaemolyticus 1.25. Determination of MBC value against Escherichia coli 2.50, Klebsiella pneumonia 2.50, Listeria monocytogenes 0.63, Pseudomonas aerugiNosa 2.50, Proteus mirabilis 2.50, Staphylococcus aureus 1.25, Salmonella typhimurium 1.25, Vibrio cholerae 1.25, Vibrio parahaemolyticus 1.25 [11].

Table 1: Antibacterial activity of S.polyanthum

\begin{tabular}{|c|c|c|c|c|c|c|}
\hline No & Sample & $\begin{array}{c}\text { Part } \\
\text { of } \\
\text { Plants }\end{array}$ & Method & Bacteria & Results & Ref. \\
\hline 1. & Ethanolic extract & Leaves & $\begin{array}{l}\text { Disc diffusion } \\
\text { method and } \\
\text { determination } \\
\text { of MIC and } \\
\text { MBC value }\end{array}$ & $\begin{array}{l}\text { Escherichia coli, } \\
\text { Klebsiella } \\
\text { pneumonia, Listeria } \\
\text { monocytegenes, } \\
\text { Pseudomonas } \\
\text { aerugiNosa, Proteus } \\
\text { mirabilis, } \\
\text { Staphylococcus aureu } \\
\text { s, Salmonella } \\
\text { typhimurium, Vibrio } \\
\text { cholerae, Vibrio } \\
\text { parahaemolyticus }\end{array}$ & $\begin{array}{l}\text { Inhibits Escherichia coli, Klebsiella } \\
\text { pneumonia, } \\
\text { monocytogenes, Psteria } \\
\text { aerugiNosa, Proteus } \\
\text { Staphylococcus aureus, Salmonirabilis, } \\
\text { typhimurium, Vibrio cholerae, } \\
\text { Vibrio parahaemolyticus }\end{array}$ & [11] \\
\hline 2. & $\begin{array}{l}S . \quad \text { polyanthum } \\
\text { chitosan } \\
\text { nanoparticles } 1 \%\end{array}$ & Leaves & $\begin{array}{l}\text { Disc diffusion } \\
\text { method Kirby- } \\
\text { Bauer }\end{array}$ & Streptococcus mutans & Inhibits Streptococcus mutans & [12] \\
\hline 3. & $\begin{array}{l}\text { Methanol } \\
\text { extract, aqueous } \\
\text { fraction, ethyl } \\
\text { acetate fraction, } \\
\text { n-hexane } \\
\text { fraction }\end{array}$ & Leaves & $\begin{array}{l}\text { Broth dilution } \\
\text { method }\end{array}$ & S.aureus and E.coli & $\begin{array}{l}\text { Methanol extract and its fraction of } \\
\text { S.polyanthum leaves have potential } \\
\text { antibacterial. MethaNol extract } \\
\text { induces the highest antibacterial } \\
\text { against S.aureus and E.coli }\end{array}$ & [13] \\
\hline
\end{tabular}




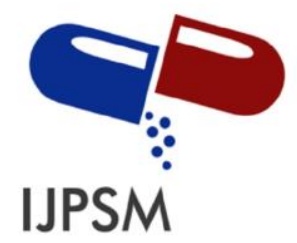

\section{Suryani Iskandi et al, Int. Journal of Pharmaceutical Sciences and Medicine (IJPSM), Vol.6 Issue. 8, August- 2021, pg. 182-186}

ISSN: 2519-9889

Impact Factor: 3.426

\begin{tabular}{|c|c|c|c|c|c|c|}
\hline 4. & $\begin{array}{l}\text { Extracts red } \\
\text { leaves n-hexane, } \\
\text { ethyl acetate, } \\
\text { ethaNol fraction }\end{array}$ & Leaves & $\begin{array}{l}\text { Agar diffusion } \\
\text { method }\end{array}$ & S.aureus and E. coli & $\begin{array}{l}\text { The highest antibacterial activity } \\
\text { against } S \text {.aureus was found in the } \\
\text { ethyl acetate fraction. } \\
\text { The highest antibacterial activity } \\
\text { against E.coli was found in the total } \\
\text { extract. }\end{array}$ & {$[14]$} \\
\hline 5. & Methanol extract & Bark & $\begin{array}{l}\text { Agar diffusion } \\
\text { method }\end{array}$ & E.coli & $\begin{array}{l}\text { The extract significantly inhibited } \\
\text { the growth of } E \text {. coli }\end{array}$ & [15] \\
\hline 6. & $\begin{array}{l}\text { S.polyanthum } \\
\text { Tannins and } \\
\text { flavonoids }\end{array}$ & Leaves & $\begin{array}{l}\text { Disc Diffusion } \\
\text { method Kirby- } \\
\text { Bauer }\end{array}$ & E. coli & Inhibits the growth of E.coli & {$[16]$} \\
\hline 7. & $\begin{array}{l}\text { Methanol, ethyl } \\
\text { acetate } \\
\text { dichloromethane, } \\
\text { ethanolic, and } \\
\text { hexane }\end{array}$ & Leaves & $\begin{array}{l}\text { Colorimetric } \\
\text { Ellman and } \\
\text { GCMS }\end{array}$ & S.aureus & $\begin{array}{l}\text { The ethanolic extract of the leaves } \\
\text { has antibacterial activity against } \\
\text { S.aureus with MBC values in the } \\
\text { range of } 10 \%-20 \% \mathrm{w} / \mathrm{v}\end{array}$ & {$[17]$} \\
\hline
\end{tabular}

Chitosan nanoparticles $1 \%$ extract S.polyanthum concentration of 100\%, 75\%, and 50\% inhibit bacterial growth S.mutans with the zone of inhibition was $13.45 \pm 0.2881,12.67 \pm 0.2733$, and $11.52 \pm 0.4070 \mathrm{~mm}$ [12]. Ampicillin as positive control showed antibacterial activities against S.aureus and E.coli with $\mathrm{IC}_{50}$ values of $37.82 \mu \mathrm{g} / \mathrm{mL}$ and $10.28 \mu \mathrm{g} / \mathrm{mL}$, respectively. Methanol extract showed antibacterial activities against S.aureus and E.coli with $\mathrm{IC}_{50}$ values of $23.16 \mu \mathrm{g} / \mathrm{mL}$ and $35.01 \mu \mathrm{g} / \mathrm{mL}$, respectively. The n-hexane fraction had the highest antibacterial activity against $S$.aureus and E.coli with an $\mathrm{IC}_{50}$ value of $49.25 \mu \mathrm{g} / \mathrm{mL}$ and $27.54 \mu \mathrm{g} / \mathrm{mL}$, respectively, compared with aqueous and ethyl acetate fractions. The results showed the antibacterial activity of methanol extract of S.polyanthum leaves and its fractions [13].

Antibacterial activity test using agar diffusion method showed that ethyl acetate fraction had the highest inhibition against S.aureus, whereas total extract had the highest inhibition against E.coli with MIC values of $0.5 \%$. These results showed that Syzygium myrtifolium extract potential as an antibacterial agent [14]. Extract concentrations of $40 \%, 60 \%$, and $80 \%$ have antibacterial activity with an average diameter of the inhibitory zone was $16.2,8.5$, and $16.3 \mathrm{~mm}$, while the positive control $27.3 \mathrm{~mm}$ and negative control $0 \mathrm{~mm}$. The statistical analysis results showed significant differences in the effects of various concentrations of methaNol extract. S. polyanthum stem bark against E.coli growth. The study concludes that the methanol extract of $S$. polyanthum's stem bark has antibacterial activity against E.coli [15].

The inhibition was obtained based on the drag zones formed around the disc paper using the sliding term. The experiment was repeated three times with the positive control (ciprofloxacin) and negative control (aquadest). The zone inhibition of $25 \%, 50 \%$, and $75 \%$ concentrations was $14 \mathrm{~mm}, 16 \mathrm{mg}$, and $20 \mathrm{~mm}$. While on the positive control was $31 \mathrm{~mm}$. The results of the inhibitory test of extract S.polyanthum against E.coli were smaller than positive control [16]. S.polyanthum had shown that boiled water of S.polyanthum at a concentration of $60 \%$ could reduce plaque index by $43.1 \pm 4.02 \%$ when the decoction was rinsed by a group of patients with fixed orthodontic appliances. These patients achieved a mean hygiene category $(31 \%-50 \%)$, 


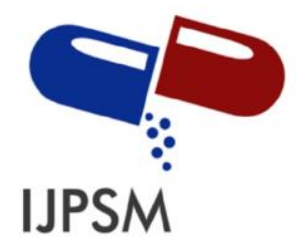

\section{Suryani Iskandi et al, Int. Journal of Pharmaceutical Sciences and Medicine (IJPSM), Vol.6 Issue. 8, August- 2021, pg. 182-186}

ISSN: 2519-9889

Impact Factor: 3.426

where the effect was comparable to chlorhexidine $(42.1 \pm 4.3 \%)$ as the gold standard of antimicrobial agents [17].

The antibacterial activity of $S$. polyanthum was related to its phytochemical content, such as flavonoids, tannins, alkaloids, phenols, saponins, steroids, and triterpenoids. Flavonoids are secondary metabolites that can inhibit bacterial growth [18]. The activity of flavonoids in inhibiting bacterial growth is by causing damage to cell membranes and inhibiting the synthesis of bacterial cell macromolecules [19].

Tannin compounds can inhibit bacterial growth. The activity of tannins in inhibiting antibacterial growth is related to their ability to bind to bacterial cell walls, inhibiting growth and protease activity. E.coli is a short rod-shaped gram-negative bacterium, facultatively anaerobic, grows well on MacConkey with round and convex colonies. Lactose fermenting and some strains of E.coli are hemolyzing blood. E.coli generally causes diarrhea worldwide. E.coli was classified according to the characteristic properties of its virulence, and each group causes disease by different mechanisms. E.coli that often cause diarrhea was classified into 5, namely: Enteropathogenic E. coli (EPEC), Enterotoxigenic E. coli (ETEC), Enterohemorrhagic E. coli (EHEC), Enteroinvasive E. coli (EIEC), Enteroaggregative E. coli(EAEC ) [20].

The ability of alkaloids to inhibit bacterial growth was related to their ability to interact with DNA, thereby inhibiting DNA synthesis and reverse transcriptase. Also, by releasing lipoteichoic acid adhesins from the cell surface, thereby interfering with membrane permeability. Saponin compounds can inhibit bacteria. The activity of saponins in inhibiting bacterial growth reduces the efficiency of glucose utilization in microorganisms, affects growth and proliferation, reduces the activity of critical enzymes in physiological metabolism, suppresses protein synthesis, and then causes cell death.

\section{Conclusion}

Based on the studies, it concludes that S.polyanthum has the potential to develop in antibacterial therapy.

\section{References}

[1]. M. Ikhwan and M. Harianja, "Review: Aktivitas Farmakologi, Senyawa Aktif dan Mekanisme Kerja Daun Salam (Syzygium polyanthum)," Perkemb. Terkini Sains Farm. dan Klin., pp. 6-7, 2015.

[2]. C. de Guzman and J.S. Siemonsma, "Plat Resources of South-Eat Asia. Backhuys Publishers, Leiden.," Vol. 19, No. 5, 2010.

[3]. S. Suharti, A. BaNowati, W. Hermana, and K.G. Wiryawan, "Komposisi dan Kandungan Kolesterol Karkas Ayam Broiler Diare yang Diberi Tepung Daun Salam (Syzygium polyanthum Wight) dalam Ransum," Media Peternak., Vol. 31, No. 2, pp. 138-145, 2008.

[4]. N. M. Wartini, HarijoNo, and T. Susanto, "Effect of Curing Process on Composition of Indonesian Bay Leaf ( Eugenia polyantha Wight .): Wight .): Components' Profile and Preference of Flavor Extracted by Simultaneous Distillation- Distillation - Extraction Method," Vol. 8, No. 1, pp. 10-18, 2007.

[5]. A. Ismail, M. Mohamed, S. A. Sulaiman, and W. A. N. Wan Ahmad, "Autonomic Nervous System Mediates the Hypotensive Effect of Aqueous and Residual MethaNolic Extracts of Syzygium polyanthum (Wight) Walp. var. polyanthum Leaves in Anesthetized Rats," 2013.

[6]. O. . Ameer, I. M. Salman, M. J. A. Siddiqui, and M. F. Yam, "Cardiovascular activity of the nbutaNol fraction of the methaNol extract of Loranthus ferrugineus Roxb.," Vol. 43, No. 2, pp. 186194, 2010.

[7]. R. M. Widhama, Ferawati, and W. D. Tamayanti, "Antidiabetic Effect of the Aqueous Extract 


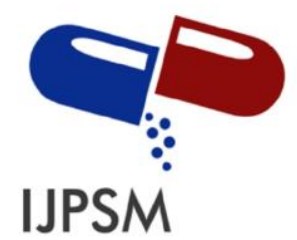

Suryani Iskandi et al, Int. Journal of Pharmaceutical Sciences and Medicine (IJPSM),

Vol.6 Issue. 8, August- 2021, pg. 182-186

ISSN: 2519-9889

Impact Factor: 3.426

Mixture of Andrographis paniculata and Syzygium polyanthum leaf," Vol. 6, No. 2, pp. 82-91, 2015.

[8]. I.W. Kusuma and H. Kuspradini, "Biological Activity and Phytochemical Analysis of Three Indonesian Medicinal Plants, Murraya koenigii, Syzygium polyanthum and Zingiber purpurea," Vol. 4, No. 1, pp. 75-79, 2011.

[9]. M. Fifendy, "Inhibitory Power Test of Medicinal Plants Extract Against Bacterial Growth MethicillinResistant Strains of Staphylococcus aureus (MRSA)," No. May, pp. 18-20, 2014.

[10].L. N and N. L. W. Musa, "Premilinary studies on phytochemical screening of ulam and fruit from Malaysia," Vol. 8, 2011.

[11].S. Ramli, S. Radu, K. Shaari, and Y. Rukayadi, "Antibacterial Activity of EthaNolic Extract of Syzygium polyanthum L. (Salam) Leaves against Foodborne Pathogens and Application as Food Sanitizer," 2017.

[12].Z. A. Siagian and H. W. Hosaina, "Uji Antibakteri Ekstrak Daun Salam (Syzygium polyanthum) Kitosan NaNopartikel 1\% Terhadap Bakteri Streptococcus mutans," Vol. 15, No. 1.

[13].N. R. Ramadhania, A. S. PurNomo, and S. Fatmawati, "Antibacterial Activity of Syzygium polyanthum Wight Leaves," Vol. 020024, No. December 2018, 2019.

[14].N. A. Haryati and E. C. Saleh, "Uji Toksisitas dan Aktivita Antibakteri Ekstrak Daun Merah Tanaman Pucuk Merah ( Syzygium myrtifolium Walp.) Terhadap Bakteri Staphylococcus aureus dan Escherichia coli," pp. 35-40.

[15].A. R. Mawan and S. E. Indriwati, "Aktivitas Antibakteri Ekstrak MetaNol Kulit Batang Tumbuhan Salam ( Syzygium polyanthum ) Terhadap Pertumbuhan Bakteri Escherchia coli," pp. 8-13, 2015.

[16].P. R. Utami and R. Ramadhani, "Uji Daya Hambat Ekstrak Daun Salam (Syzygium polyanthum [Wight] Walp) Terhadap Pertumbuhan Bakteri Escherichia Coli," 1991.

[17].A. Ismail, W. Amir, N. Wan, A. Ismail, and W. Amir, "Syzygium polyanthum (Wight) Walp: Fitomedicine Potential," Vol. 11, No. 2, pp. 429-438, 2019.

[18].I. Sukadana, "Aktivitas Antibakteri Senyawa Flavonoid dari Kulit Akar Awar-Awar (Ficus septica Burm F)," J. Kim., Vol. 4, No. 1, 63-70, 2010.

[19].J. P. Dzoyem, H. Hamamoto, B. Ngameni, B. T. Ngadjui, and K. Sekimizu, "Antimicrobial Action Mechanism of Flavonoids from Dorstenia Species," Drug Discov. Ther., Vol. 7, No. 2, pp. 66-72, 2013.

[20].M. T. W. Sisilia Dewanti, "Antibacterial Activity Of Bay Leaf Infuse (Folia Syzygium Polyanthum Wight) To Escherichia Coli In-Vitro," J. Med. Planta, Vol. 1, No. 4, 2011.

\section{A Brief Author Biography}

Suryani Iskandi - A student of bachelor's degree in the Department of Pharmacology and Clinical Pharmacy, School of Pharmaceutical Science (STIFARM) Padang, West Sumatera, Indonesia.

Fitra Fauziah - A lecturer of bachelor's degree in the Department of Pharmacology and Clinical Pharmacy, School of Pharmaceutical Science (STIFARM) Padang, West Sumatera, Indonesia.

Sri Oktavia - A lecturer of bachelor's degree in the Department of Pharmacology and Clinical Pharmacy, School of Pharmaceutical Science (STIFARM) Padang, West Sumatera, Indonesia. 